\title{
Биопрепарат для защиты и повышения урожайности лука
}

\section{В.П. Цветкова, В.С. Масленникова}

В 2017-2018 годах исследовано ростостимулирующее и фунгицидное действие биологического препарата на луке в условиях Новосибирской области. В результате установлено, что биопрепарат Фитоп 8.67 (ООО НПФ «Исследовательский центр») на основе бактерий рода Bacillus оказывает фунгицидное действие в отношении фузариоза, аспергиллеза и пероноспороза репчатого лука, а также способствует увеличению урожая луковиц на 20\%.

Ключевые слова: лук сорта Штутгартер Ризен, биологический препарат, Фитоп 8.67, урожайность.
$\Pi$ о данным Федеральной службы государственной статистики в Новосибирской области в 2017 году посевные площади под овощную продукцию составили 7285 тыс. га, из них 6507 тыс. га - территории личных подсобных хозяйств населения (90\%) [1]. В личных подсобных хозяйствах зачастую применяют химические средства защиты растений, при этом практически не используют средства индивидуальной защиты при работе с пестицидами. При неправильном использовании химических пестицидов происходит их накопление не только в окружающей среде, но и в продуктах питания и организме человека. Это может стать причиной ухудшения здоровья и появления хронических заболеваний. Экологически безопасной альтернативой химическим пестицидам служат биологические препараты, созданные на основе природных микробных агентов регуляции численности фитопатогенов. Бактерии рода Bacillus наиболее продуктивны по синтезу антибиотиков и подавляют рост фитопатогенных микроорганизмов. Ряд российских исследователей выделили разные штаммы культуры этой бактерии, что привело к созданию ассортимента биопрепаратов на основе $B$. subtilis [2, 3]. Один из таких препаратов - Фитоп 8.67.

Цель работы - оценка фунгицидного и ростостимулирующего действия Фитопа 8.67 на луке репчатом.

Условия, материал и методы исследований. Объекты исследования: лук сорта Штутгартер Ризен, Фитоп 8.67 (смесь штаммов Bacillus amyloliquefaciens ВКПМ В-10642, B. amyloliquefaciens ВКПМ
В-10643, В. subtilis ВКПМ В-10641, препарат предоставлен ООО НПФ «Исследовательский центр» Новосибирск, Кольцово), в качестве биологических эталонов: Бактофит (Bacillus subtilis штамм ИПМ-215) и Фитоспорин М (Bacillus subtilis штамм 26 D, 100 млн кл/г), в качестве химического эталона - Максим Дачник, КС (25 г/л флудиоксонила).

Исследования проводили на базе научной лаборатории кафедры защиты растений Новосибирского государственного аграрного университета и УПХ «Сад Мичуринцев» согласно общепринятым методикам [4].

Луковицы замачивали в препаратах (Фитоп 8.67 в концентрации $10^{6}$ КОЕ/мл, остальные препараты согласно инструкции) на 1 час, контроль - в воде. Обработанные луковицы высаживали рядами в трех повторностях по 100 штук. Испытания проводили на естественном фоне заболеваний в полевых условиях. Качество урожая оценивали по средним пробам с каждого варианта в каждой повторности.

В особо важный период вегетации культуры в 2017 году - фазе со-

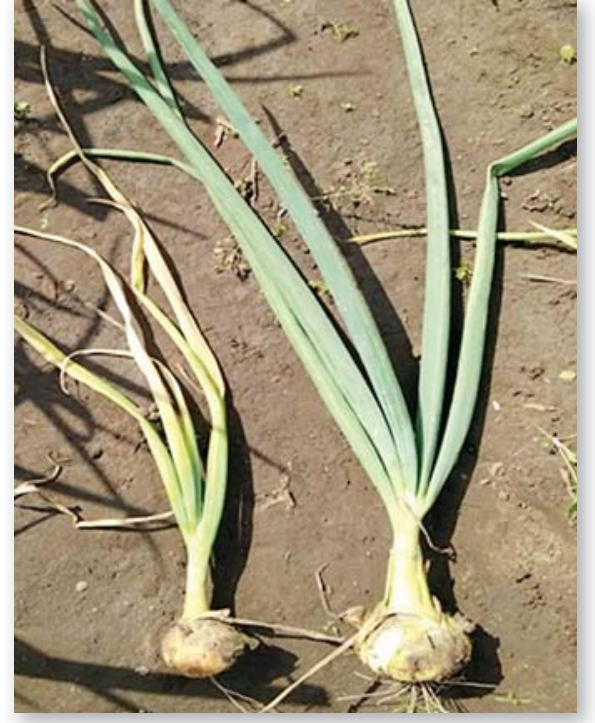

Pис. 1. Пораженность листьев лука Peronospora destructor Casp. (слева - контрольный вариант, справа - Фитоп 8.67)

зревания луковиц (конец июня-начало июля) - погодные условия характеризовались повышенным количеством осадков (ГТК за июнь и июль составил 1,3 и 1,6 соответственно), что способствовало распространению болезней на луке. Погодные условия 2018 года благоприятствовали росту и развитию лука

Опыты закладывали на выщелоченном среднемощном черноземе (по механическому составу - тяжелосуглинистом, иловато-крупно-пылеватом), с плотностью почвы

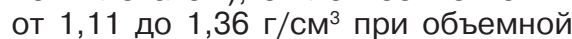
массе в слое почвы 0-27 см - 1,06 г/

Таблица 1. Влияние биопрепаратов на рост надземной части лука, 2017-2018 годы

\begin{tabular}{|c|c|c|c|c|c|c|c|c|}
\hline \multirow{3}{*}{ Вариант } & \multicolumn{8}{|c|}{ Длина надземной части, см } \\
\hline & \multicolumn{2}{|c|}{ I декада июля } & \multicolumn{2}{|c|}{ II декада июля } & \multicolumn{2}{|c|}{ III декада июля } & \multicolumn{2}{|c|}{ I декада августа } \\
\hline & 2017 & 2018 & 2017 & 2018 & 2017 & 2018 & 2017 & 2018 \\
\hline Контроль & 38,8 & 38,5 & 41,18 & 39,6 & 53,5 & 41,1 & 51 & 43,1 \\
\hline Фитоп 8.67 & 39,9 & 46,1 & 45,38 & 46,9 & 55,8 & 47 & 57,6 & 48,8 \\
\hline Фитоспорин М & 34,1 & 39,8 & 46,18 & 40 & 52 & 43,4 & 53,1 & 45,3 \\
\hline Бактофит & 38,9 & 38,6 & 51,4 & 42,8 & 53,4 & 46,9 & 53,6 & 47,5 \\
\hline Максим Дачник & 38 & 40,8 & 47,6 & 42,1 & 50,4 & 43 & 51,8 & 44,2 \\
\hline
\end{tabular}




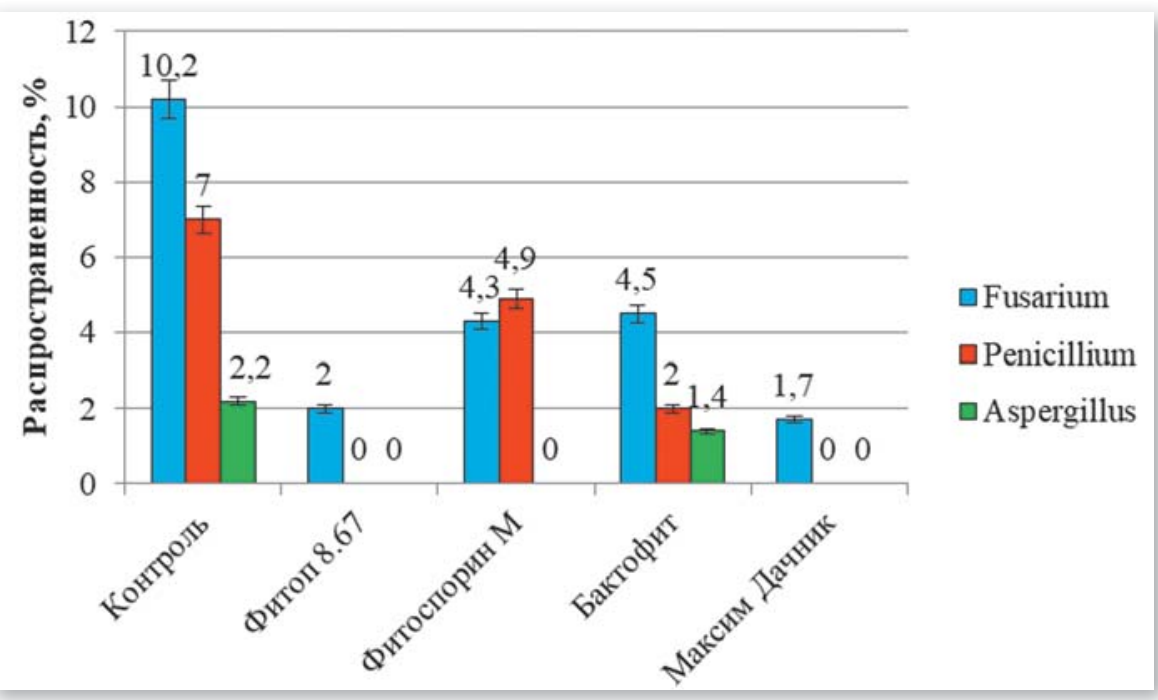

Рис. 2. Фунгицидное действие биопрепаратов

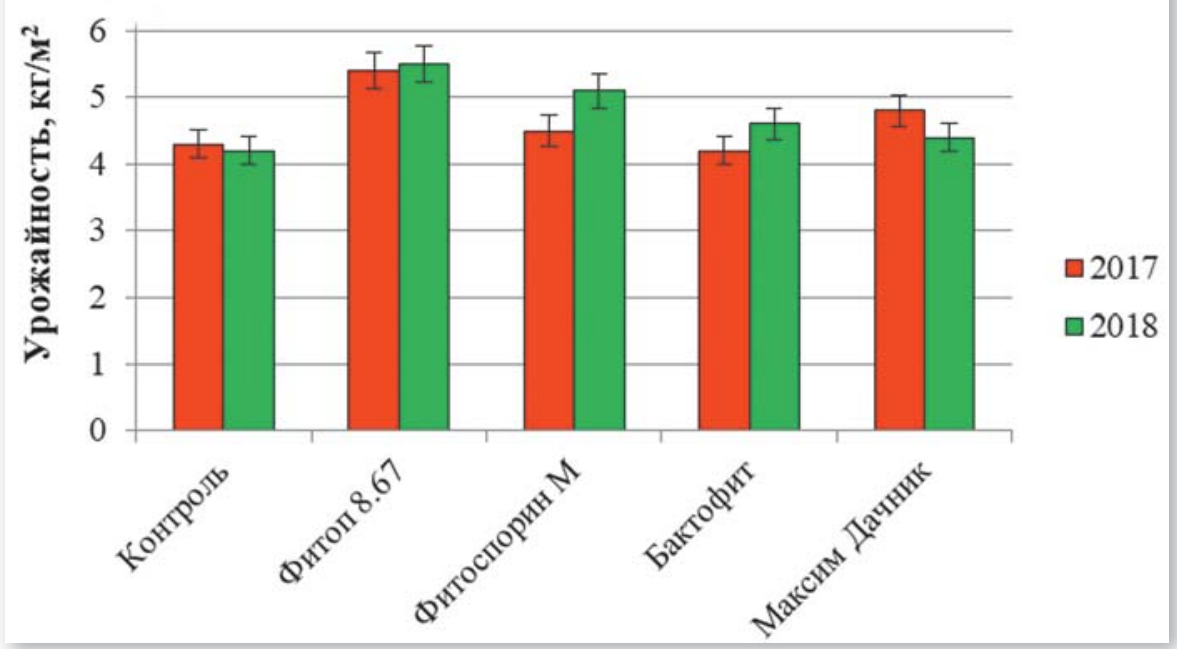

Рис. 3. Влияние биопрепаратов на урожай лука

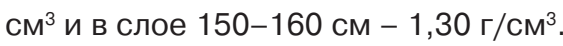
Содержание гумуса составило 4,5$6,2 \%$, валового азота - 0,19-0,36, фосфора - 0,15-0,21 и калия - 1,101,26\%. Содержание легкогидролизуемого азота колебалось в пределах
8,10-12,6 мг, подвижного фосфора $18,2-25,1$ и обменного калия - 9,4012,1 мг на 100 г почвы, $\mathrm{pH}$ солевой вытяжки 6,62.

Цифровой материал полученных результатов обрабатывали диспер-

Таблица 2. Влияние биопрепаратов на количество листьев на растении, 2017-2018 годы

\begin{tabular}{|c|c|c|c|c|c|c|c|c|}
\hline \multirow{3}{*}{ Вариант } & \multicolumn{8}{|c|}{ Число листьев на одном растении, шт. } \\
\hline & \multicolumn{2}{|c|}{ І декада июля } & \multicolumn{2}{|c|}{ II декада июля } & \multicolumn{2}{|c|}{ III декада июля } & \multicolumn{2}{|c|}{ IV декада августа } \\
\hline & 2017 & 2018 & 2017 & 2018 & 2017 & 2018 & 2017 & 2018 \\
\hline Контроль & 4,8 & 4,7 & 5,6 & 5,4 & 6,1 & 6 & 6,3 & 6,1 \\
\hline Фитоп 8.67 & 6 & 6,9 & 7,2 & 6,9 & 7,3 & 7 & 7,4 & 7,2 \\
\hline Фитоспорин М & 3,3 & 4,9 & 3,6 & 5,5 & 4 & 5,6 & 4,4 & 5,7 \\
\hline Бактофит & 4,5 & 5,3 & 6,4 & 5,5 & 6,5 & 6,4 & 6,6 & 6,6 \\
\hline Максим Дачник & 5,3 & 5,4 & 5,6 & 5,9 & 5,6 & 5,9 & 5,7 & 6 \\
\hline
\end{tabular}

сионным методом с помощью пакета программы СНЕДЕКОР [5].

Результаты исследований. В результате обработки луковиц препаратом Фитоп 8.67, всхожесть луковиц возросла и составила, в среднем за два года, 95,5\%. Этот показатель в вариантах с применением Бактофита и Фитоспорина соответственно составил 89,5-88,0\%, а с препаратом Максим Дачник - 86,0\%. В фазе образования луковиц, распространенность фузариоза в контрольном варианте составила 12,3\%, в варианте с применением Фитоспорина М - 7,0\%, а с Фитопом 8.67-1,6\% (снизилась в 7,7 раза). В фазе полегания листьев начал развиваться пероноспороз (Peronospora destructor Casp) лука. Распространенность болезни снизилась относительно контроля при применении: Фитопа 8.67 в 1,9 раза, Фитоспорина М - в 2,4 раза, Бактофита - в два раза, Максима Дачника - в 1,6 раза (рис. 1). В период вегетации при применении Фитопа 8.67 увеличивались морфометрические показатели (табл. 1, 2). Влияние физиологически активных веществ, продуцируемых бациллами, оказало ростостимулирующее действие: высота надземной части и количество листьев статистически достоверно было выше в варианте с применением Фитопа 8.67 по всем срокам учета и превышало контрольный вариант в 1,2 раза. Биологические эталоны показали хорошие результаты только по высоте растений, а химический эталон был на уровне контроля.

При анализе луковиц нового урожая была выявлена зараженность грибами родов Fusarium, Penicillium и Aspergillus. Наиболее распространенными возбудителями были грибы рода Fusarium (рис. 2), распространенность которых в контроле достигала $10 \%$, а применение Фитопа 8.67 снизило ее в пять раз, что было практически на уровне химического эталона. Грибы других родов в этом варианте не обнаружены.

Обработка посадочного материала препаратом Фитоп 8.67, независимо от погодных условий двух вегетационных периодов, позволила получить более высокий (в 1,3 раза по сравнению с контролем) и стабильный урожай за счет фунгицидного и стимулирющего действия смеси штаммов рода Bacillus (рис. 3), в то время как статистически достоверных различий с контролем в эталонных вариантах не получено, кроме варианта с применением Фитоспорина-М в 2018 году. 
Заключение. Таким образом, смесь биоагентов препарата Фитоп 8.67 проявила многофункциональное действие на луке: стимулировала рост и развитие растений, оздоравливала от патогенной микрофлоры, способствовала повышению урожайности. Для снижения распространенности фитопатогенного гриба Peronospora destructor Casp. и возбудителей, вызывающих гнили лука, а также, повышения продуктивности и качества нового урожая лука репчатого рекомендуется обрабатывать луковицы перед посадкой Фитопом 8.67 к концентрации $10^{6}$ KOE/мл.

\section{Библиографический список}

1.Федеральная служба государственной статисти ки. Посевные площади сельскохозяйственных культур по категориям хозяйств в Новосибирской области. [Электронный ресурc]. URL: http://www.gks.ru/ (дата обращения: 16.10.2018)

2.Штерншис М.В. Тенденции развития биотехнологии микробных средств защиты растений в России // Вестник Томского государственного университета. Биология. 2012. № 2 (18). С. 92-100.

3.Штерншис М.В. Биопрепараты в защите растений учеб. Пособие. Минсельхоз РФ. Новосиб. гос. аграр. ун-т / под общ. ред. М.В. Штерншис. Новосибирск, 2000. $128 \mathrm{c}$

4.Литвинов С.С. Методика полевого опыта в овощеводстве. М.: ВНИИО-РАСХН, 2011. 636 с.

5.Доспехов Б.А. Методика полевого опыта (с основами статистической обработки результатов исследований). М.: Альянс, 2014. 350 с.

\section{Об авторах}

Цветкова Вера Павловна, канд. С. х. наук, доцент кафедры защиты растений, ФГБОУВО Новосибирский ГАУ.

E-mail:vera.cvetkova.23.05@mail.ru

Масленникова Владислава

Сергеевна, аспирант, ФГБОУВО

Новосибирский ГАУ

E-mail: vladislava.maslennikova@mail.ru

Biological preparation for protection and yield increase of onion

V.I. Tsvetkova, $P h D$, associate professor, department of plant protection, Novosibirsk State Agrarian University.

E-mail: vera.cvetkova.23.05@mail.ru V.S. Maslennikova, postgraduate of the Novosibirsk State Agrarian University. E-mail: vladislava.maslennikova@mail.ru

Summary. In 2017-2018, the growth-promoting and fungicidal action of a biological preparation on onions in Novosibirsk region was investigated. As a result, it was established that the biological preparation Fitop 8.67, based on bacteria of the genus Bacillus, has a fungicidal effect on Fusarium, Aspergillus and Peronospora destructor on onions, and also contributes to increasing yield by $20 \%$.

Keywords: onion variety Stuttgarter Riesen, biological preparation, Fitop 8.67, yield.

\section{Курсы апробации \\ по подготовке агрономов-апробаторов овощных, бахчевых и цветочных культур}

При поддержке Министерства науки и высшего образования и Министерства сельского хозяйства РФ, Федеральное государственное бюджетное научное учреждение «Федеральный научный центр овощеводства" (ФГБНУ ФНЦО) ФНЦО в период с 7 по 18 августа 2019 года проводят курсы по подготовке агрономов-апробаторов овощных, бахчевых и цветочных культур. Адрес: 143072, Московская обл., Одинцовский р-н, пос. ВНИИССОК, ул. Селекционная, 14. Оплата обучения на курсах составляет 22500 руб. Проживание в гостинице. После обучения будут выданы: удостоверение об окончании курсов, пакет нормативных, а также отчетных документов (договор, счет, счет-фактура). В рамках курсов предусмотрена: экскурсия в РГАУ-МСХА имени К.А. Тимирязева.

На все ваши вопросы (проезд, оплата гостиницы и т.д.) ответят по телефонам: 8 (495) 59924-42 (приемная директора), 8 (495) 599-13-22 (главный бухгалтер), 8 (495) 594-77-24, e-mail: pavlov.l.v@vniissok.ru (ответственный за проведение курсов - д.с.-х.н., профессор Павлов Леонид Васильевич). Подробная информация на сайте: www.vniissok.ru

* Федеральный научный центр овощеводства» утвержден базовой организацией по повышению квалификации специалистов государств-участников СНГ по вопросам селекции и семеноводства овощных культур.

\section{Серёжа Саркисович Ванеян}

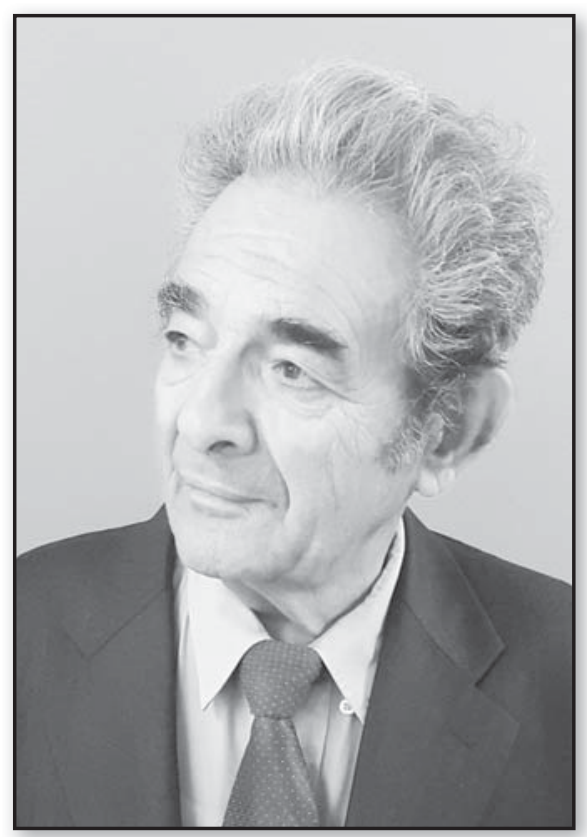

(15.09.1930-21.12.2018)

22 декабря на 89 году жизни скоропостижно скончался выдающийся ученый, Заслуженный деятель науки РФ, главный научный сотрудник ВНИИО - филиала ФГБНУ ФНЦО, доктор с.-х. наук, профессор Серёжа Саркисович Ванеян.

Серёжа Саркисович был ведущим специалистом в области орошения в овощеводстве и бахчеводстве. В последние годы занимался разработкой ресурсосберегающих режимов орошения и применения минеральных удобрений при выращивании высокоурожайных сортов и гибридов овощных культур отечественной и зарубежной селекции.
Родился С.С. Ванеян близ озера Севан в знаменитом древними хачкарами армянском селе Норадуз в семье крестьянина. Оставшийся без отца в восьмилетнем возрасте, старший из четверых детей, он с малых лет познал нелегкий труд на земле. В 1947 году он успешно окончил среднюю школу и поступил на гидротехнический факультет Ереванского политехнического института. После окончания института его направили в Среднюю Азию, где он готовил молодых специалистов.

С 1963 года Серёжа Саркисович работал во ВНИИ овощеводства. За время работы в институте он разработал единую методику определения водного режима овощных и бахчевых культур при разных способах полива в различных регионах страны, занимался совершенствованием технологии работы высокопроизводительных дождевальных машин и капельного орошения. Разработанный им и внедренный в серийное производство гидроподкормщик ГПД-50 заменил в производстве зарубежные аналоги.

С.С. Ванеян имел более 179 опубликованных работ, 11 авторских свидетельств и патентов на изобретение, подготовил 13 кандидатов наук. Он был принципиальным, требовательным к себе и другим, доброжелательным человеком.

Коллективы ФГБну
Агрхолдинга “Поиск", уче-
ые-овощеводы, друзья, кол-
еги, ученики, редакция журна-
а «артофель и овощи" скорбят
кончине Серёжи Саркисовича,
ыражают глубокие и искрен-
ие соболезнования его семье и
лизким.

